\begin{tabular}{|c|c|c|}
\hline & Int.J.Curr.Microbiol.App.Sci (2021) 10(08): 234-239 & \\
\hline & $\begin{array}{l}\text { International Journal of Current Microbiology and Applied Sciences } \\
\text { ISSN: 2319-7706 Volume } 10 \text { Number } 08 \text { (2021) } \\
\text { Journal homepage: } \underline{\text { http://www.ijcmas.com }}\end{array}$ & $\$$ \\
\hline $\begin{array}{l}\text { EXCELLENT } \\
\text { PUBLISHERS }\end{array}$ & & "nww.ijcmas.com \\
\hline
\end{tabular}

\title{
Individual Donor Nucleic Acid Testing for HIV, HBV and HCV among Blood Donors in a Tertiary Care Hospital
}

\author{
A. Shalini Priya ${ }^{1}$, B. R. Sunitha ${ }^{2}$, K. S. Rajashekar ${ }^{3}$, R. Lava ${ }^{2}$, Mamatha Patil ${ }^{4}$, \\ Savitha Devi ${ }^{4}$ and Neelambika ${ }^{5}$ \\ ${ }^{1}$ Department of Microbiology, Government Karur Medical College, Karur-636 009, \\ Tamil Nadu, India \\ ${ }^{2}$ Department of Microbiology, ${ }^{3}$ Department of Pathology, J.J.M.Medical College, \\ Davangere, India \\ ${ }^{4}$ Blood Bank Officer, Chigateri District Hospital, Davangere, India \\ ${ }^{5}$ Medical Superintendent Chigateri District Hospital, Davangere, India \\ *Corresponding author
}

\section{A B S T R A C T}

Transfusion-transmitted infections (TTIs) continue to be a threat to safe transfusion practices. A total of 30 million blood components are transfused each year in India. Blood safety thus becomes a top priority, especially with a population of around 1.23 billion and a high prevalence rate of human immunodeficiency virus (HIV) in general population in India. Nucleic acid testing

Keywords

HIV, ID-NAT, TTIs

Article Info

Accepted:

15 July 2021

Available Online:

10 August 2021
(NAT) in blood donor screening has been implemented in many developed countries to reduce the risk of transfusion-transmitted viral infections(TTIs). The objective was to assess the role of individual donor-NAT (ID-NAT) for human immunodeficiency virus-1 (HIV-1) its role in blood safety. It involves voluntary blood donors during period of one year from $1^{\text {st }}$ June 2016 to May 2017 attending Chigateri Blood Bank, Davangere. Over a period of 1 year from $1^{\text {st }}$ June 2016 to $31^{\text {st }}$ May 2017, a total number of 9423 blood donor samples were subjected to test for HIV by Individual Donor Nucleic acid testing (ID-NAT), 9402 donors (99.8\%) were negative by ID-NAT. 21 donors $(0.2 \%)$ were positive by ID-NAT. Most of donors were in age group of 20-29 years \& sex ratio of male: female was 70:1.Maximum donors belonged to $\mathrm{O}$ blood group. NAT could detect HIV cases in blood donor samples. Its widespread use in blood banks would ensure additional layer of safety in blood transfusion.

\section{Introduction}

Infection with human immunodeficiency virus (HIV), which causes AIDS has become a worldwide epidemic and is one of the major public health concerns for all countries. ${ }^{(1,2)}$

The HIV prevalence at national level has 
continued its steady decline from an estimated peak of $0.38 \%$ in $2001-03$ through $0.34 \%$ in 2007 and $0.28 \%$ in 2012 to $0.26 \%$ in 2015 . $^{(3)}$ Overall, India's HIV epidemic is slowing down with a $32 \%$ decline in new HIV infections. $^{(4)}$

Blood safety status in India is challenging task with a population of more than 134 crores \& with at least 2.1 million HIV infected individuals $(0.24 \%-0.3 \%)$ among general population. India is the home for third largest HIV epidemic in the world after South Africa \& Nigeria. ${ }^{(5,6)}$ In India as per the regulatory requirement of the Drug and Cosmetics act of 1940, (1st Amendment rules 1992) it is mandatory to test each donated unit of blood for markers of HIV- I and II, HBV, HCV, Malaria and Syphilis ${ }^{(7)}$.

A single unit of blood or its components may be transfused into as many as 1-4 recipients and thereby spreading HIV infection quite rapidly. ${ }^{(8)}$

Currently, in India all the blood donations are screened for various infectious markers using ELISA or rapid methods. The NAT tests of high sensitivity rely on amplification of intended regions of viral nucleic acid for detection. The purpose of this study is to provide better understanding of the role of NAT in reduction of the risk of acquiring TTIs. NAT testing is not yet mandatory for screening blood units in India but has been started in a few centers to enhance blood safety ${ }^{(9)}$.

NAT detects infection before serological tests 9.4 days earlier for HIV $-1 .^{(10)}$.

The objective was to assess the role of individual donor-NAT (ID-NAT) for human immunodeficiency virus-1 (HIV-1) its role in blood safety.

\section{Materials and Methods}

\section{Study Design and settings}

Around 9423 voluntary blood donors during period of one year from $1^{\text {st }}$ June 2016 to $31^{\text {st }}$ May 2017 were included. Permission from Hospital authorities and ethical clearance from institutional ethical committee were obtained before starting the study.

All samples were subjected to ELISA for HIV reactivity, irrespective of its results were subjected to the reference center for ID-NAT, where multiplex PCR company employed by Karnataka Government under "TOWARDS ZERO RISK BLOOD” Program at Bowring \&Lady Curzon Hospitals attached to Bangalore Medical College \& Research Institute.

\section{Specimen Collection}

With strict aseptic precautions, $10 \mathrm{ml}$ of venous blood sample was collected by vein puncture.

From that, $7 \mathrm{ml}$ of blood was directly collected in EDTA vacutainer for obtaining plasma and was processed for ID-NAT (Individual Nucleicacid Amplification Testing) using Procleix Ultrio Plus Assay by qualitative in-vitro Nucleicacid Amplification Test as per standard protocol supplied by manufacturer (i.e Novartis Diagnostics, Emeryville, California) Year 2012-07, 502432 Rev.A.).

Remaining $3 \mathrm{ml}$ of blood was collected in plain vacutainer and was centrifuged to get serum and was tested/processed for HIV antibodies by using SD HIV1/2 ELISA 3.0 KIT (Third Generation of Anti-HIV1/2 ELISA) according to standard protocol supplied by manufacturer (i.e, Sd Bio Standard Diagnostics Pvt. Ltd, Haryana, India) Year 2014, SD/02/IB/96/0100.) 


\section{Sample subjected to two tests}

ID-NAT (Individual Nucleicacid Amplification Test)

\section{HIV $1 \&$ 2ELISA}

The test was run in batches once in 3-4 days. In our study we followed two-step procedure, transcription of the RNA to cDNA is performed first. Transcription occurs between $40^{\circ} \mathrm{C}$ and $50^{\circ} \mathrm{C}$, depending on the properties of the reverse transcriptase enzyme utilized. Products of that reaction are then amplified in a separate reaction.

\section{Results and Discussion}

The observations made from the study are shown in the following tables.

Among 9423 blood donors, highest no. of donors were in the age group of 20-29 years, 6038 donors $(64.1 \%)$ and least in the $>60$ years age group, 15 donors $(0.16 \%)$. Other groups were $433(4.6 \%)$ in the age group $<20$ yrs, 2375(25.2\%) in the age group 30-39 yrs, $515(5.5 \%)$ in the age group 40-49 yrs and $47(0.5 \%)$ in the age group 50-59 yrs.

Out of 9423 donors, maximum (3175) were $\mathrm{O}$ +ve group comprising $33.7 \%$ and least were AB-ve (30) comprising $0.3 \%$. From the table.3, majority of donors were Rh+ve 9104 $(96.6 \%) \& \mathrm{Rh}-$ ve were $319(3.4 \%)$.

Among 9423 donors, 9402 (99.8\%) were negative and $21(0.2 \%)$ were positive by only ID-NAT. In the present ID-NAT study which is first ever in Davangere, 9423 blood donors samples were tested for a one year period from $1^{\text {st }}$ June 2016 to $31^{\text {st }}$ May 2017 attending Chigateri Blood Bank.

Maximum no of donors were in age group of 20-29 yrs (64.1\%). Though the age criteria for donor selection was followed in Bareeto et al., study, studies by Chatterjee et al., \& Sharma et al., had adolescent blood donors. It could be due to inclusion of adolescents with enthusiasm for voluntary blood donation or due to social/peer pressure.

Most of the donors were males $98.6 \%$ with sex ratio of 70:1 similar to the observations in all other studies like Chatterjee $\mathrm{K}$ et al., ${ }^{(11)}$, Rao and Annapurna et al., ${ }^{(12)}$ and Rose et al., ${ }^{(13)}$

Most of the donors in our study belong to O+ve blood group (33.7\%), and it correlates well with studies P K Das et al., ${ }^{(14)}$ Apecu et al., ${ }^{(15)}$ \& Das et al. ${ }^{(16)}$.O is the most common blood group among general population and is commonly regarded as universal donor \& most needed group for patients.

In present study, the HIV ID-NAT positive percentage was $(0.2 \%)$ which was high when compared with study by Rajesh et al., ${ }^{(17)} 43$ $(0.06 \%)$ out of 32,978 donor samples.

The reason for high percentage of HIV IDNAT in present study could be that our blood bank is attached to Government Tertiary Care Hospital \& many patients most of times comes from economical weaker sections \& HIV is more common in people from lower socioeconomic status. ${ }^{(18)} \&$ also NAT can pick up at 4.7(4-5) days of entry of HIV virus in blood.

The percentage of HIV positive cases in our study $(0.2 \%)$ correlates well with study by Makroo et al., ${ }^{(19)}$ but their sample size was large \& it was undertaken for duration of 11 years. Another reason for low percentage of HIV positive donors may be availability of $4^{\text {th }}$ Generation ELISA and reduction of false positive cases due to increased specificity of the test. 
Table.1 Age wise distribution of voluntary blood donors

\begin{tabular}{|c|c|c|}
\hline Age In years & Frequency & Percentage \\
\hline$<\mathbf{2 0}$ & 433 & $\mathbf{4 . 6}$ \\
\hline $\mathbf{2 0 - 2 9}$ & 6038 & $\mathbf{6 4 . 1}$ \\
\hline $\mathbf{3 0 - 3 9}$ & 2375 & $\mathbf{2 5 . 2}$ \\
\hline $\mathbf{4 0 - 4 9}$ & 515 & $\mathbf{5 . 5}$ \\
\hline $\mathbf{5 0 - 5 9}$ & 47 & $\mathbf{0 . 5 0}$ \\
\hline$\geq \mathbf{6 0}$ & 15 & $\mathbf{0 . 1 6}$ \\
\hline Total & $\mathbf{9 4 2 3}$ & $\mathbf{1 0 0 . 0}$ \\
\hline
\end{tabular}

Table.2 Sex wise distribution of voluntary blood donors

\begin{tabular}{|c|c|c|c|}
\hline Gender & Frequency & Percentage & \multirow{2}{*}{ Ratio } \\
\hline Male & 9290 & 98.6 & \\
\cline { 1 - 3 } Female & 133 & 1.4 & \multirow{7}{*}{$\mathbf{7 0}: \mathbf{1}$} \\
\hline Total & $\mathbf{9 4 2 3}$ & $\mathbf{1 0 0 . 0}$ & \\
\hline
\end{tabular}

Table.3 Blood groups distribution among voluntary blood donors

\begin{tabular}{|c|c|c|}
\hline Blood Group & Frequency & Percentage \\
\hline A+ve & 2265 & $\mathbf{2 4 . 0}$ \\
\hline B+ve & 3033 & $\mathbf{3 2 . 2}$ \\
\hline O+ve & 3175 & $\mathbf{3 3 . 7}$ \\
\hline AB+ve & 631 & $\mathbf{6 . 7}$ \\
\hline AB-ve & 30 & $\mathbf{0 . 3}$ \\
\hline A-ve & 89 & $\mathbf{0 . 9}$ \\
\hline B-ve & 86 & $\mathbf{0 . 9}$ \\
\hline O-ve & 114 & $\mathbf{1 . 2}$ \\
\hline Total & $\mathbf{9 4 2 3}$ & $\mathbf{1 0 0 . 0}$ \\
\hline
\end{tabular}

Table.4 Distribution of Rh Blood Groups among blood donors

Rh Positive Blood Groups 9104(96.6\%)

\section{Rh Negative Blood Groups} $319(3.4 \%)$

Table.5 Results of HIV ID-NAT among voluntary blood donors

\begin{tabular}{|c|c|c|}
\hline ID-NAT & No. of Cases & Percentage \\
\hline Positive & 21 & 0.2 \\
\hline Negative & 9402 & $\mathbf{9 9 . 8}$ \\
\hline Total & 9423 & $\mathbf{1 0 0 . 0}$ \\
\hline
\end{tabular}


The reason for higher yield in our study could be that our Blood Bank is attached to Government Tertiary Care Center and many patients most of times comes from economical weaker section where as study by Stramer et al., ${ }^{(20)}$ was carried out in non-Government organizations.

Since viremia precedes sero conversion by several days in cases of HIV infection, so routine implementation of ELISA \& NAT in blood banks can be significant step to achieve the goal of "Towards Zero Risk Blood" a programme by Karnataka Government.

NAT helps to detect potentially infectious blood units in all phases of infection which in turn helps in enchancing the safety of the blood and blood components for transfusion.

\section{Acknowledgments}

Authors would like to thank my guide Dr. Sunitha B.R. M.D., Professor, Department of Microbiology, J.J.M Medical College, Davangere, for her guidance, constant support and encouragement. I express my gratitude to Professor \& HOD, Dr. R. Lava M.D., for his guidance and constant support throughout my study. I am highly grateful to Medical Superintendent Dr. H.D. Neeleembika M.D., Blood Bank Medical Officers Dr. Mamatha Patil M.D., \& Dr. Savitha Devi M.D. Also authors thank to the staff of Blood centre Chigateri District hospital for their cooperation.

\section{References}

1. United States Centers for Disease control and Prevention. HIV Surveillance- United States,1981-2008.2012., WHO Report. Global Summary of the AIDS epidemic.WorldHealthOrganization 2009.

Availablefrom:http://www.who.int/hiv/dat a/ 2009_global_summary.png [Last
Accessed 2012 Feb 4].

2. NACO Online. HIV Sentinel Surveillance and HIV Estimation 2007-A Technical Brief 2007.

3. Sharma R. R. Cheema R, Vajpayee M, Rao U, Kumar S, Marwaha $\mathrm{N}$, et al., Prevalence of markers of transfusion transmissible diseases in voluntary and replacement blood donors. Natl Med J Ind2004;17:19-21.

4. Dodd R. Y. Notari E P $4^{\text {th }}$, Stramer S. L. Current prevalence and incidence of infectious disease markers and estimated window-period risk in the American Red Cross blood donor population. Transfusion 2002;42:975-9

5. Chaurasia R, Zaman S, Das B, Chatterjee K. Screening Donated Blood for Transfusion Transmitted Infections by Serology along with NAT and Response Rate to Notification of Reactive Results: An Indian Experience. Journal of blood transfusion.2014;pg 6.

6. Negi G, Gaur D. Trends of Transfusion Transmissible Diseases Among Blood Donors at Uttarakhand, India. Indian $J$ Community Med.2014 Jul-Sep;39(3):183186.

7. UNAIDS, 2006. Report on the Global AIDS Epidemic.HIV and AIDS estimates and data 2005 and 2003.

8. India HIV Estimations 2015.Technical Report. NACO \& National Institute of Medical Statistics, ICMR. Ministry of Health \& Family Welfare. Government of India.pg no.2.

9. Kurien T, Thyagarajan S P, Jeyaseelan L, Peedicayil A, Rajendran P, Sivaram S, et $a l$., Community prevalence of hepatitis $\mathrm{B}$ infection and modes of transmission in Tamil Nadu, India. Indian $J$ Med Res. 2005;121:670-5.

10. Kaur P, Basu S. Transfusion-transmitted infections: Existing and emerging pathogens. J PostgradMed.2005;51:14651. 
11. Chatterjee $\mathrm{K}$, Coshic $\mathrm{P}$, Borgohain $\mathrm{M}$, Premchand, Thapliyal R M, Chakroborty $\mathrm{S}$, Sunder $\mathrm{S}$ et al., Individual donor nucleic acid testing for blood safety against HIV-1 and hepatitis $\mathrm{B}$ and $\mathrm{C}$ viruses in a tertiary care hospital. The National Medical Journal of India, 2012;25(4):207-209.

12. Rao P, Annapurna K. HIV status of blood donors and patients admitted in KEM Hospital Pune. Indian J Hemat Blood Transf1994;12:174-6

13. Dolly R, Annie S, Thaiyanayaki P, Babu George P, Hohn Jacob T. Increasing prevalence of HIV antibody among blood donors monitored over 9 years in blood donors monitored over 9 years in blood bank. Indian J Med Res1998;108:42-4.

14. P K Das, S C Nair, V K Harris, D Rose, J J Mammem, Y N Bose, Sudarsanam. Distribution of $\mathrm{ABO}$ and Rh-D Blood Groups among Blood donors in a tertiary Care Centre in South India. TropicalDoctor,2001;31(1).

15. Apecu, Richard Onyuthi et al., "ABO and Rhesus (D) Blood Group Distribution among Blood Donors in Rural South Western Uganda: A Retrospective Study." BMC Research Notes 9 (2016): 513. PMC. Web. 28 Sept.2017.
16. Das $\mathrm{R}$ N, Joshi $\mathrm{H}$ S, Biswas $\mathrm{R}$. Opportunistic infections and clinic epidemiological factors in HIV/AIDS cases seen in a tertiary care hospital in Nepal. African Journal of Clinical and ExperimentalMicrobiology.2005;6(3):239 $-245$.

17. Kumar R, Gupta S, Kaur A, Gupta M. Individual donor-nucleic acid testing for human immunodeficiency virus1,hepatitis $\mathrm{C}$ virus and hepatitis $\mathrm{B}$ virus and its role in blood safety. Asian Journal of Transfusion Science.2015;9(2):199202.

18. Aidala A, Cross J E, Stall R, Harre D, Sumartojo E. Housing status and HIV risk behaviors:Implications for prevention and policy. AIDS and Behavior 2005;9:25165.

19. Makroo R N. Impact of routine individual blood donor nucleic acid testing(IDNAT) for HIV-1,HCV and HBV on blood safety in a tertiary care hospital. Apollo Med2007;4:9-12.

20. Stramer S L, Glynn S A, Kleinman S H, Strong D M, Caglioti S, Wright D J, et al.,. Detection of HIV-1 and HCV infections among antibody-negative blood donors by nucleic acid amplification testing N Engl J Med. 2004;351:760-8.

\section{How to cite this article:}

Shalini Priya, A., B. R. Sunitha, K. S. Rajashekar, R. Lava, Mamatha Patil, Savitha Devi and Neelambika. 2021. Individual Donor Nucleic Acid Testing for HIV, HBV and HCV among Blood Donors in A Tertiary Care Hospital. Int.J.Curr.Microbiol.App.Sci. 10(08): 234-239. doi: https://doi.org/10.20546/ijcmas.2021.1008.027 